\title{
MOLECULAR BIOLOGY OF THE APTERONOTUS NMDA RECEPTOR NR1 SUBUNIT
}

\author{
ROBERT J. DUNN ${ }^{1,2,3, *}$, DANIELE BOTTAI ${ }^{1, \$}$ AND LEONARD MALER ${ }^{4}$ \\ ${ }^{1}$ Center for Research in Neuroscience, Montreal General Hospital Research Institute, 1650 Cedar Avenue, Montreal, \\ Quebec, Canada H3G 1A4, ${ }^{2}$ Department of Biology and ${ }^{3}$ Department of Neurology, McGill University, Montreal, \\ Quebec, Canada H3G $1 A 4$ and ${ }^{4}$ Department of Anatomy and Neurobiology, University of Ottawa, Ottawa, Ontario, \\ Canada K1H 8 M5 \\ *Author for correspondence at address 1 (e-mail: mc81@musica.mcgill.ca) \\ $\ddagger$ Present address: Max-Planck Institute for Medical Research, 69120 Heidelberg, Germany
}

Accepted 25 January; published on WWW 21 April 1999

\begin{abstract}
Summary
The complete sequences and expression patterns of the NR1 (aptNR1) subunit of the $N$-methyl-D-aspartate (NMDA) receptor and its alternative splice isoforms have been determined for the weakly electric fish Apteronotus leptorhynchus. The deduced amino acid sequence of aptNR1 is approximately $88 \%$ identical to the NR1 sequences of other vertebrate. Two of the three alternative splice cassettes previously described for mammalian NR1s, $\mathrm{N} 1$ and $\mathrm{C} 1$, are present in aptNR1, but the third cassette, $\mathrm{C} 2$, is not found. In addition, two teleost-specific splice cassettes occur on the $\mathrm{N}$-terminal side of the $\mathrm{C} 1$ sequence. The cellular patterns of aptNR1 expression, including the

system, with the highest levels in electrosensory lateral line lobe pyramidal cells. Expression of the N1 splice isoform was higher in more caudal regions of the brain, and expression of the $\mathrm{C} 1$ splice isoform was higher in more rostral regions. The $\mathrm{N} 1$ splice isoform was present in almost all NR1-positive cells, in contrast to the $\mathrm{C} 1$ splice isoform which was restricted to a subset of NR1-positive cells. These results demonstrate that the NR1 subunit of the NMDA receptor is evolutionarily conserved across species and that regulation of alternative RNA splicing modulates the properties of NR1 in different neurons of the central nervous system of A. leptorhynchus.
\end{abstract} patterns of $\mathrm{N} 1$ and $\mathrm{C} 1$ splicing, have been mapped using the in situ hybridization technique. High levels of aptNR1 mRNA were detected throughout the central nervous system including most neurons of the electrosensory

Key words: electrosensory system, NMDA receptor, NR1 subunit, alternative RNA splicing, Apteronotus leptorhynchus, NR1 amino acid sequence homology.

\section{Introduction}

Glutamate is the principle excitatory neurotransmitter of the teleost central nervous system (CNS), as it is for other vertebrates. The properties of glutamatergic synaptic transmission are determined by the kinetics of glutamate release from the presynaptic terminal and by the kinetics, ion selectivity and conductances of the glutamate receptors on the postsynaptic membrane. We have begun an investigation of the molecular mechanisms that control glutamate synaptic transmission within the electrosensory system of the electric fish Apteronotus leptorhynchus. We describe here some molecular properties of the NR1 subunit of the N-methyl-Daspartate (NMDA) class of postsynaptic glutamate receptors in this system and compare these with the properties of the mammalian NR1 subunit.

Studies of mammalian neurons have shown that postsynaptic membranes contain a variety of glutamate receptors which are broadly classified into two families, ionotrophic and metabotropic. The ionotrophic receptors form cation channels that are activated directly by the binding of glutamate, while the metabotropic receptors regulate ion

channels indirectly through the trimeric G-protein intracellular signaling pathways. The ionotrophic receptors are subclassified as AMPA ( $\alpha$-amino-3-hydroxy-5-methyl-4isoxazole propionate), kainate or NMDA types depending on their responses to specific agonists. Members of each receptor group differ in kinetics, voltage-dependencies and regulation, and the properties of the synaptic response therefore depend on which specific receptor types are assembled at the postsynaptic site. For example, NMDA receptors typically produce slower, longer-lasting responses than AMPA/kainate receptors; therefore, synapses containing NMDA receptors produce longer-lasting excitatory postsynaptic currents (EPSCs) than synapses containing only AMPA/kainate types (Hestrin et al., 1990; Nicoll et al., 1990). In fact, many glutamate synapses contain both NMDA and non-NMDA receptors, and synaptic responses typically reflect the properties of both receptor types (Forsythe and Westbrook, 1988; Lester et al., 1990).

NMDA receptors display three unique properties critical to the control of excitatory synaptic transmission. First, activation 
of the NMDA receptor depends on the simultaneous binding of two agonists, glutamate released from synaptic vesicles and glycine from the extrasynaptic fluids (Johnson and Ascher, 1987; Kleckner and Dingledine, 1988). Thus, glycine levels can act to modulate NMDA receptor responses. Second, NMDA receptors depend on a depolarized membrane potential for activation due to blockage of the ion pore by $\mathrm{Mg}^{2+}$ from the extrasynaptic space (MacDonald et al., 1982; Mayer et al., 1984; Nowak et al., 1984). This voltage-dependence for activation allows the glutamate synapse to function as a cellular coincidence detector where full synaptic response occurs only when there is coincident depolarization through the activation of adjacent synaptic sites. In this way, the synapse becomes dependent on the simultaneous activity of more than one synapse. Third, the NMDA receptor is highly permeable to $\mathrm{Ca}^{2+}$, which activates intracellular signals that can modify synaptic function. These unique properties of the NMDA receptor have been implicated in a number of brain processes including neuronal differentiation, synaptic plasticity and neurotoxicity.

The NMDA receptor is a tetrameric protein complex containing two different types of subunit, NR1 and NR2 (Hollmann and Heinemann, 1994; Laube et al., 1998). The functional receptor is assembled from two NR1 and two NR2 subunits (Fig. 1A). There are multiple subtypes of both NR1 and NR2. In rodents, eight different NR1 receptor subtypes are generated from a single gene through the utilization of alternative RNA splicing (Anantharam et al., 1992; Durand et al., 1993; Hollmann et al., 1993; Sugihara et al., 1992). In contrast, the four different NR2 subunits (NR2A/2B/2C/2D) are encoded by four separate genes (Ikeda et al., 1992; Ishii et al., 1993; Kutsuwada et al., 1992; Meguro et al., 1992; Monyer et al., 1992). Studies in which different NR1 and NR2 subunits are co-expressed in vitro have established that different combinations of NR1 and NR2 can form functional receptor complexes, but that their properties will vary depending on the subunits in the complex (Ishii et al., 1993; Meguro et al., 1992; Monyer et al., 1992; Vicini et al., 1998).

The molecular complexity of the NMDA receptor that results from the selective assembly of different NR1 and NR2 subunits suggests that glutamate synaptic responses can be effected by the selective expression of the different receptor subunits within neurons. This idea has been supported by studies mapping NR1 and NR2 gene expression in rodent brain, which have revealed a complex mosaic of NR1 and NR2 expression within different neuronal populations (Buller et al., 1994; Dunah et al., 1996; Ishii et al., 1993; Johnson et al., 1996; Landwehrmeyer et al., 1995; Laurie et al., 1995; Laurie and Seeburg, 1994; Monyer et al., 1994; Paupard et al., 1997; Petralia et al., 1994a; Standaert et al., 1994, 1996). Our studies of the Apteronotus NMDA receptor investigated whether different subunits are selectively expressed in the neurons of the electrosensory system and how the pattern of receptor expression affects synaptic transmission.

At the level of protein secondary structure, both the NR1 and NR2 subunits are thought to form structures similar to those proposed for non-NMDA receptors, as illustrated in Fig. 1B (Hollmann et al., 1994; Wo and Oswald, 1994). Four structural domains are defined within this structure: (i) the amino-terminal region forms the extracellular surface of the receptor; (ii) two segments, $\mathrm{S} 1$ which lies just $\mathrm{N}$-terminal to the first transmembrane segment and S2 which lies between the third and fourth transmembrane segments, form the ligandbinding pocket (O'Hara et al., 1993; Stern-Bach et al., 1994); (iii) the transmembrane core of the receptor is formed by three helices TM1, TM3 and TM4 and a pore-forming P region; (iv) the carboxy-terminal intracellular domain is the site of intracellular protein-protein interactions and also contains the sites for protein kinase modulation of the receptor.

\section{Amino acid sequence of the teleost NR1 subunit}

We have recently determined the cDNA and deduced amino acid sequences of the aptNR1, the NR1 subunit of teleost Apteronotus leptorhynchus (Bottai et al., 1998). Fig. 2 illustrates this sequence and indicates sequence homologies to orthologous receptors from frog, duck, rat and human. The aptNR1 amino acid sequence, excluding the alternatively spliced segments, is approximately $88 \%$ identical to the other vertebrate NR1s. Sequence homologies are most pronounced in the carboxyl half of the protein, where only eight amino acid positions are divergent (homology more than 98\%) in the segment stretching between aptNR1 amino acid 486 and the site of carboxy-terminal alternative splicing. This highly conserved segment includes the three proposed transmembrane segments, the pore segment and the ligand-binding domains. Included in the highly conserved region is segment $\mathrm{C} 0$, which occurs immediately following the final transmembrane helix TM4 (Fig. 1B). C0 contains one of the two calmodulin-binding sites in NR1; the other is present in segment $\mathrm{C} 1$, as discussed below. Calmodulin binding to $\mathrm{C} 0$ inhibits NMDA receptors and is proposed to cause the use-dependent desensitization of NMDA EPSCs mediated by $\mathrm{Ca}^{2+}$ influx (Ehlers et al., 1996; Zhang et al., 1998). The very high sequence conservation of these critical functional domains of aptNR1 suggests that the pharmacology and functional properties associated with mammalian NR1 subunits are likely to be conserved to a large extent in aptNR1. Future studies will test this hypothesis directly by electrophysiological analysis of recombinant fish NMDA receptor subunits expressed in cultured animal cells.

\section{Alternative RNA splicing generates NR1 subunit isoforms}

Although there appears to be only a single gene encoding the NR1 subunit in all vertebrate species analyzed to date, a variety of different subtypes of the NR1 subunit are produced by alternative RNA splicing at one site in the extracellular amino-terminal domain and at two sites in the intracellular carboxy-terminal domain (Anantharam et al., 1992; Bottai et al., 1998; Durand, 1993; Hollmann et al., 1993; Sugihara et al., 1992). In Fig. 1B, the types of alternative splice segment found in aptNR1 are compared with the those in the mammalian NR1. 
A

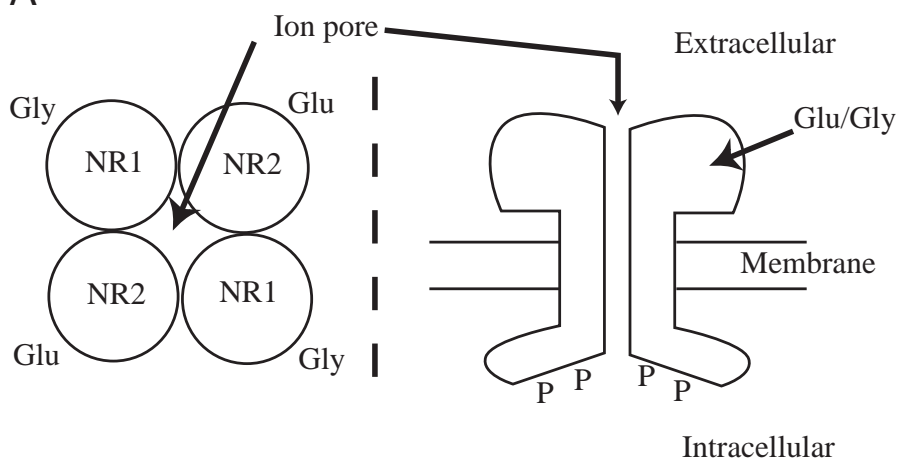

Fig. 1. Structure of the $N$ methyl-D-aspartate (NMDA) receptor complex. (A) The NMDA receptor contains four subunits, two NR1 and two NR2 subunits. The ion conduction pore lies in the center of the complex. Glu, glutamate; Gly, glycine; P, phosphate. (B) The proposed secondary structures for NR1 from rat and Apteronotus leptorhynchus. The shaded area includes the regions in which the amino acid sequences are nearly identical. The boxed segments labeled N1, C1, $\mathrm{C}^{\prime}, \mathrm{C} 1^{\prime \prime}, \mathrm{C} 2$ and $\mathrm{C}^{\prime}$ indicate the positions of alternatively spliced cassettes. The boxed segments $\mathrm{S} 1$ and $\mathrm{S} 2$ indicate the ligand-binding domains. Segment C0 is highly conserved.

B

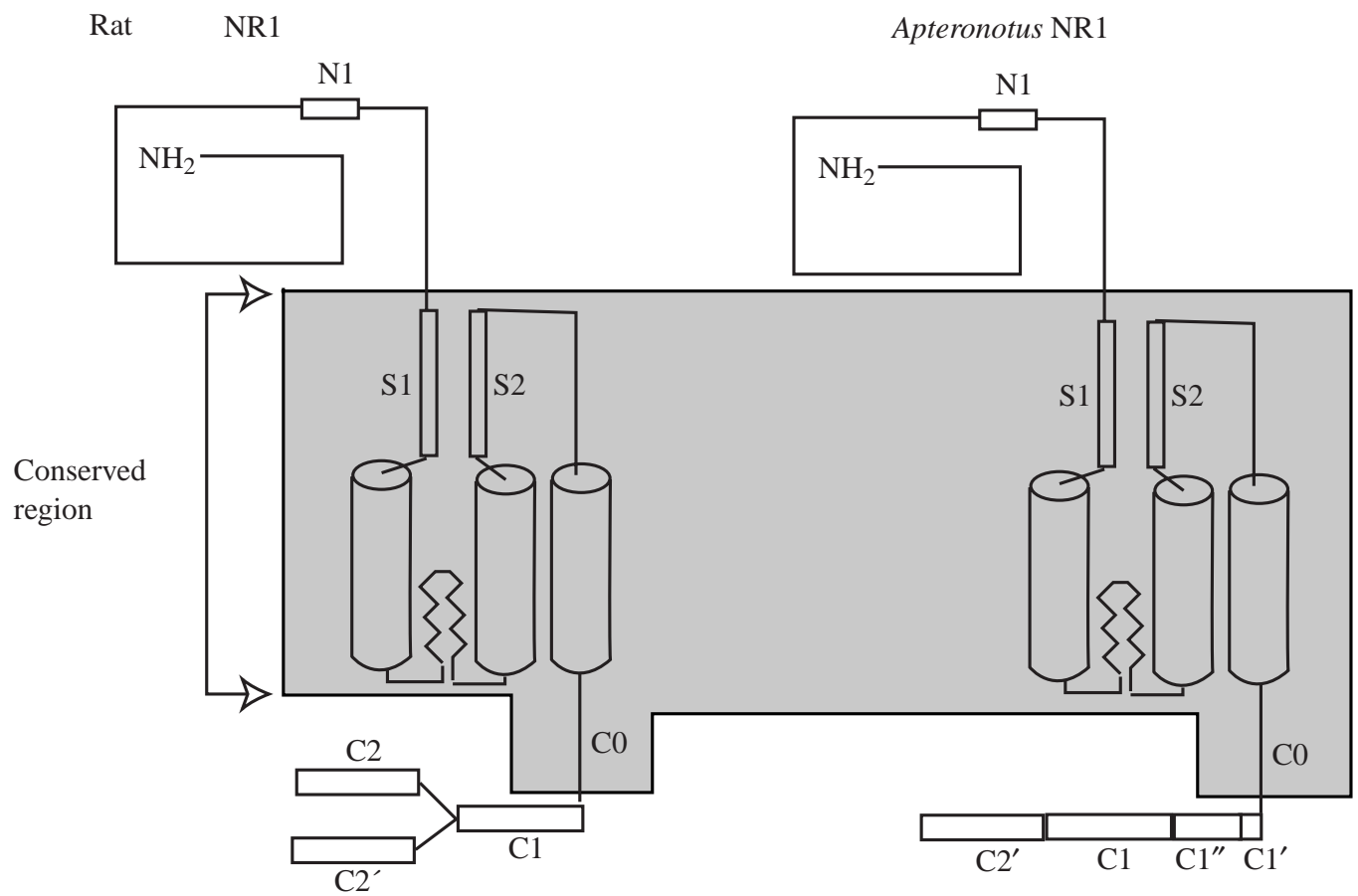

The fish NR1 contains splice cassettes corresponding to two of the three mammalian cassettes, $\mathrm{N} 1$ in the amino-terminal domain and $\mathrm{C} 1$ in the carboxy-terminal domain. In addition, two carboxy-terminal domain splice cassettes $\mathrm{Cl}^{\prime}$ and $\mathrm{Cl}^{\prime \prime}$ are present in aptNR1 but have not been detected in mammals. The C2 splice cassette appears to be an evolutionary development of mammalian NR1 that is absent from both the fish and frog sequences (Soloviev et al., 1996).

\section{Expression of NMDA receptors in Apteronotus central nervous system}

The relative levels of NR1 subunit gene expression provide an estimate of overall NMDA receptor synthesis because NR1 is an obligate component for all functional NMDA receptors. We have used both RNase protection and in situ hybridization assays to determine the levels of NR1 expression in the CNS of Apteronotus (Bottai et al., 1997). Similar to the results in

mammalian systems (Laurie et al., 1995; Moriyoshi et al., 1991; Petralia et al., 1994b), NMDA receptors are expressed in most regions of the fish brain, with the highest levels in forebrain and hypothalamus. One striking difference is the very low level of expression in fish cerebellar Purkinje cells, which express high levels of NR1 in mammals (Laurie et al., 1995; Petralia et al., 1994b; Watanabe et al., 1994). However, the functional significance of this difference is unclear because, despite high levels of NR1 expression, mammalian Purkinje cells do not express functional NMDA receptors (Farrant and Cull-Candy, 1991; Krupa and Crepel, 1990; Perkel et al., 1990).

Consistent with the findings that NMDA receptor mediated synaptic responses are involved in several levels of electrosensory processing (Bastian, 1993; Berman et al., 1997; Dye et al., 1989; Heiligenberg et al., 1996; Maler and Monaghan, 1991), many cells of the electrosensory system exhibit robust expression of NR1 (Bottai et al., 1997). In the 
electrosensory lateral line lobe (ELL), the pyramidal cells express high levels of NR1, higher than any other cell type in the brain. When compared across the four segments of the ELL, pyramidal cells of the central medial segment (CMS) express significantly higher levels $(134 \%)$ than those of the lateral segment (LS), which may relate to the tuning of CMS pyramidal cells to lower-frequency inputs than those in the LS (Shumway, 1989a,b). The very high level of NR1 expression in ELL pyramidal cells is probably required to maintain NMDA receptors in the very extended apical dendritic structures, which are rich in glutamate synapses (Berman et al., 1997; Maler and Monaghan, 1991).

Moderate levels of NR1 expression were detected in most of the interneurons in the ELL (Bottai et al., 1997). Granule cells, ovoid cells, polymorphic cells and neurons of the ventral molecular layer all express NR1. As expected, spherical cells, which receive gap-junction synaptic inputs from T-type electroreceptor afferents, show no evidence of NR1 expression. Moderate NR1 expression was detected in most cells at higher levels of the electrosensory system, including the torus semicircularis, nucleus praeminentialis and optic tectum. In the medullary pacemaker nucleus, both pacemaker and relay cells express moderate levels of NR1.

The results described above indicate that NMDA receptors are present in neurons that are involved with most levels of electrosensory processing. In particular, the very high level of NMDA receptor expression in ELL pyramidal cells provides an ideal system for detailed molecular and physiological investigations of the contribution of NMDA receptors to synaptic transmission during sensory processing.

\section{Alternative RNA splicing in the amino-terminal domain of aptNR1}

As shown in Fig. 1B, alternative RNA splicing produces two isoforms of NR1 which differ in the presence or absence of the N1 segment in the amino-terminal domain. The sites and sequences of N1, a segment of 21 amino acid residues, are highly conserved among species (Fig. 2). The effects of N1 on NMDA receptor function have been investigated by expression of recombinant receptors in cultured animal cells and Xenopus laevis oocytes. These studies indicate that the presence of $\mathrm{N} 1$ in NR1 results in receptors that display higher current amplitudes (Hollmann et al., 1993; Zheng et al., 1994), reduced affinity for glycine (Durand et al., 1993; Hollmann et al., 1993; Nakanishi et al., 1992), resistance to proton inhibition (Traynelis et al., 1995) and are not potentiated by polyamines such as spermine (Durand et al., 1993). Recently, two elements, $\mathrm{Zn}^{2+}$ released into the synaptic cleft and intracellular tyrosine kinases of the src family, have been shown to cooperate in the regulation of NMDA receptor function (Zheng et al., 1998). NMDA currents are suppressed by low concentrations of extracellular $\mathrm{Zn}^{2+}$; however, this suppression is removed by tyrosine kinase phosphorylation of the receptor NR2 subunits. This mechanism could, in principle, allow intracellular control of NMDA receptor currents through second messengers that control tyrosine kinase activities. Interestingly, NMDA receptors that contain NR1 subunits with the N1 insert are relatively resistant to inhibition by low concentrations of extracellular $\mathrm{Zn}^{2+}$ and are therefore not as dependent on activation by the tyrosine kinase pathway (Traynelis et al., 1998). Thus, the control of N1 alternative splicing provides two functionally distinct NMDA receptor populations at the synapse, N1- receptors, which require activation of the tyrosine kinase signaling system for full activity, and N1+ receptors, which are constitutively active. The presence of these two functionally distinct NMDA receptor types could provide very different synaptic responses that may have important consequences for synaptic transmission within functional neuronal networks.

We have used the RNase protection assay to determine the percentage of NR1 subunits that contain N1 in different regions of the Apteronotus CNS (Bottai et al., 1998). In general, NMDA receptors in the forebrain contain lower levels of the $\mathrm{N} 1+\mathrm{NR} 1$ subunit $(8 \%)$ than more caudal regions such as the brainstem $(43 \%)$. This result may indicate that NMDA responses in the brainstem are generally less subject to modulation by intracellular tyrosine kinase mechanisms than are those in the forebrain, where synaptic plasticity is a more relevant feature.

At the cellular level, we have detected N1 transcripts in most neurons that express the NR1 gene. For example, ELL pyramidal cells and granule cells contain both $\mathrm{N} 1+$ and $\mathrm{N} 1-$ receptors. One exception were the pyramidal cells of the optic tectum, which contained only a very low level of N1+ mRNA. Possibly, tyrosine kinase modulation is particularly important for the control of NMDA responses in these cells. Overall, our results indicate that most neurons in the CNS of Apteronotus express both N1+ and $\mathrm{N} 1-$ receptor types, but that the levels of $\mathrm{N} 1+$ are reduced in more rostral regions. An important question that remains is to determine the distribution of $\mathrm{N} 1+$ and $\mathrm{N} 1-$ receptors among the different synaptic populations in this system.

\section{Alternative RNA splicing in the carboxy-terminal domain of aptNR1}

In mammals, a complex pattern of alternative RNA splicing occurs within the carboxy-terminal domain of NR1 (Fig. 1B).

Fig. 2. Sequence comparison of the NR1 proteins. The Apteronotus leptorhynchus NR1 protein sequence (aptNR1) is shown and compared with NR1 sequences of Xenopus laevis (Soloviev et al., 1996), duck (Kurosawa et al., 1994), rat (Moriyoshi et al., 1991; Anantharam et al., 1992) and human (Foldes et al., 1993; Karp et al., 1993; Planells-Cases et al., 1993). Residues that are identical to the aptNR1 sequence are omitted in the other sequences. Positions of deletions are indicated by dashes (-). The amino acid positions are indicated on the right. TM1, TM3 and TM4 indicate the putative transmembrane segments, and $\mathrm{P}$ indicates the proposed pore segment. Glycosylation (filled squares), protein kinase C (filled circles) and protein kinase $\mathrm{A}$ (asterisk) are indicated above the aptNR1 sequence. $\mathrm{N} 1, \mathrm{C} 1, \mathrm{C}^{\prime}$ and $\mathrm{C}^{\prime \prime}$ indicate the positions of the alternatively spliced cassettes. SS indicates the signal sequence. 
Apteronotus

Xenopus

Duck

Rat

Human

Apteronotus

Xenopus

Duck

Rat

Human

Apteronotus

Xenopus

Duck

Rat

Human

Apteronotus

Xenopus

Duck

Rat

Human

Apteronotus

Xenopus

Duck

Rat

Human

Apteronotus Xenopus

Duck

Rat

Human

Apteronotus

Xenopus

Duck

Rat

Human

Apteronotus Xenopus

Duck

Rat

Human

Apteronotus Xenopus

Duck

Rat

Human

Apteronotus

Xenopus

Duck

Rat

Human

Apteronotus

Xenopus

Duck

Rat

Human
SS

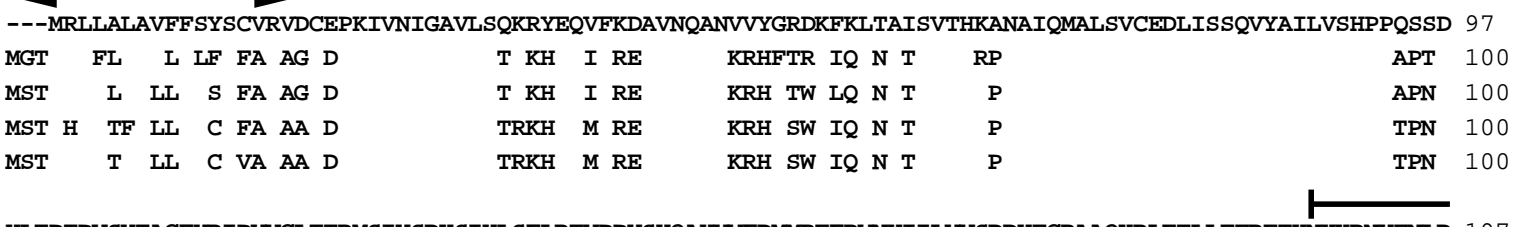

HLTPTPVSYTAGFYRIPVVGLTTRMSIYSDKSIHLSFLRTVPPYSHQAHVWFDMMREFRWNHIILVVSDDHEGRAAOKRLETLLEERETKNKKRNYENLD 197

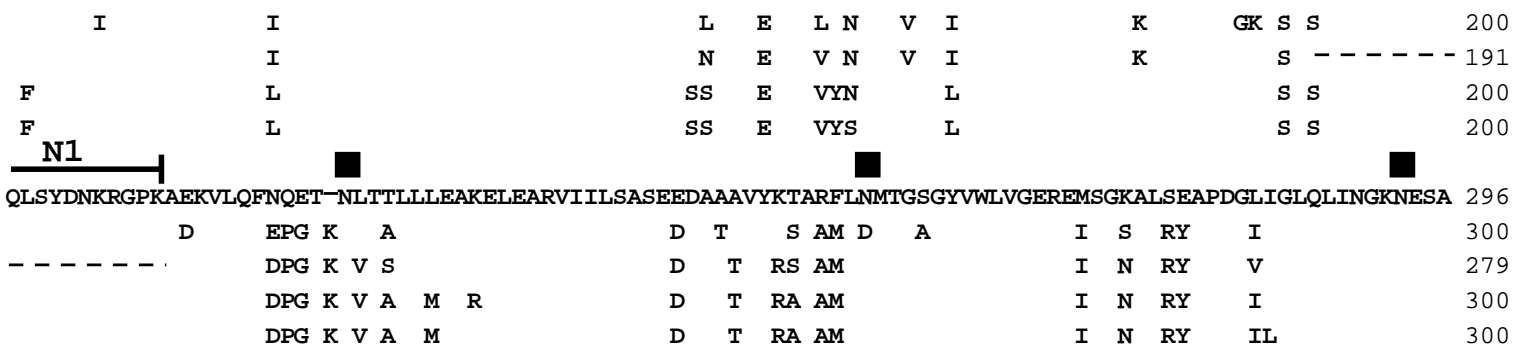

HISDAVGVVAQSIQELFEKENITEPPRGCVGNTNIWKTGPLFKRVLMSSKYPEGLTGRVEFNDDGDRKYAHYSILNYQKSRLVQVGIYNGTQVVLNKQRK 396

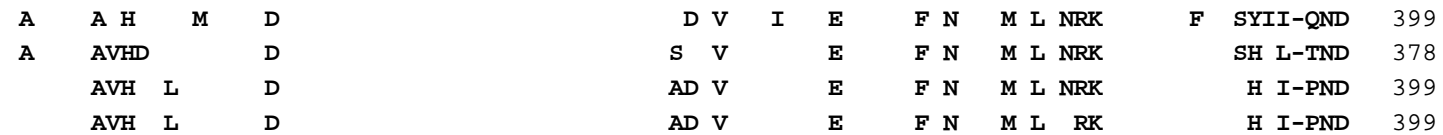

IIWPGGETERPRGFQMSTRLKIVTIHQEPFVYVKPTLMDGTCKEEHTPNGVLIKKVICTGPNETIPGRP-TVPOCCYGFCIDLLIKLAMTMNFTYEVHL 494

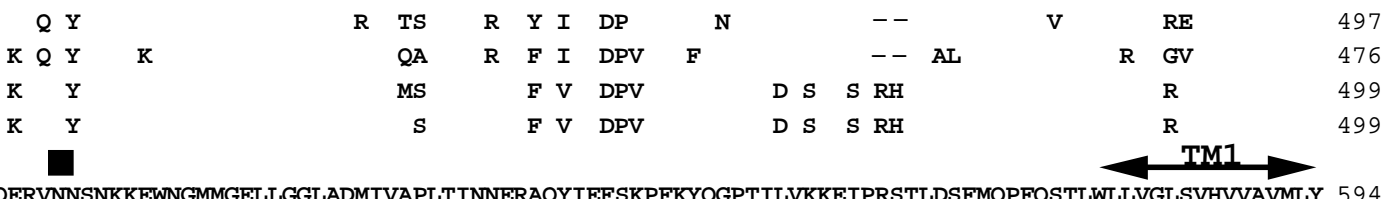

VADGKFGTQERVNNSNKKEWNGMMGELLGGLADMIVAPLTINNERAQYIFFSKPFKYQGPTILVKKEIPRSTLDSFMOPFQSTLWLLVGLSVHVVAVMLY 594

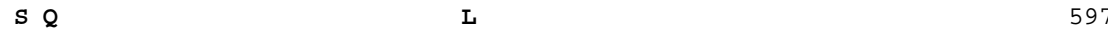

S O

$\begin{array}{lll}S \text { Q } & \text { L } & 599\end{array}$

S O $\quad$ L 259

LLDRFSPFGRFKVNSEEEEEDALTLSSAMWFSWGVLLNSGIGEGAPRSFSARILGMVWAGFAMIIVASYTANLAAFLVLDRPEERITGINDPRLRNPSDK 694

FIYATVKOSSVDIYFRRQVELSTMYRHMEKHNYESAAEAIQAVRDNKLHAFIWDSAVLEFEASQKCDLVTTGELFFRSGFGIGMRKDSPWKQNVSLAILS 794

TM4

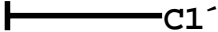

SHENGFMEDLDKTWVRYOECDSRSNAPATLTFENMAGVFMLVAGGIAAGIFLIFIEIAYKRHKDARGKOMOLAFAAVNVWRKNLQDNKESAGSOIAGAAG 894

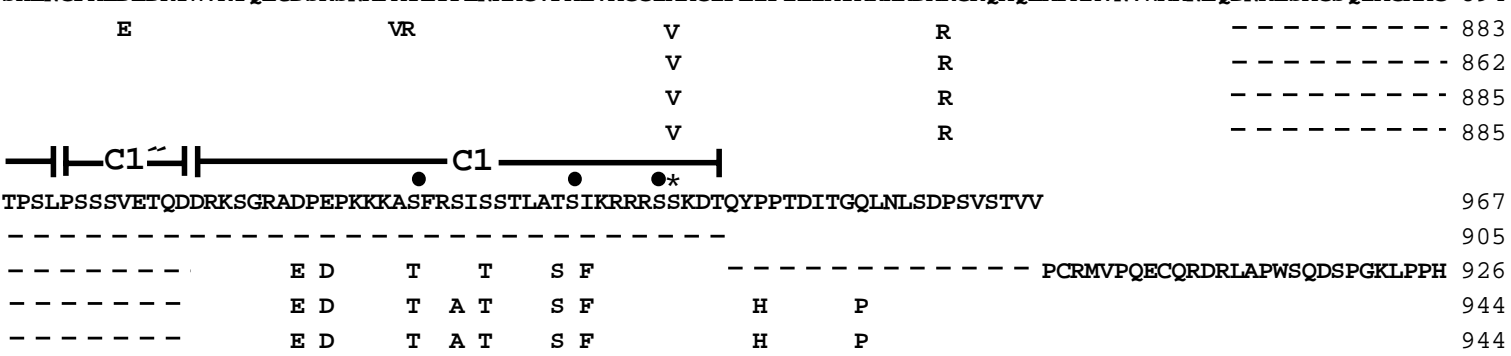

SERPSAHHHPSCTASPRHIIPTAPGGDACVPHROLLOLE 
Two alternative splice cassettes, $\mathrm{C} 1$ and $\mathrm{C} 2$, can be present. The carboxyl terminus of NR1 is encoded by segment $\mathrm{C} 2$, or in the absence of $\mathrm{C} 2$ by a segment termed $\mathrm{C}^{\prime}$. There are significant differences in this pattern for the aptNR1 gene. We have been unable to identify a $\mathrm{C} 2$ segment in fish mRNA, which suggests that fish lack the $\mathrm{C} 2$ cassette. Thus, all fish NR1 proteins would contain the $\mathrm{C} 2^{\prime}$ sequence at their carboxyl terminus. Because $\mathrm{C}^{2}$, but not $\mathrm{C} 2$, contains a PDZ recognition motif, this means that all fish NR1 subunits can interact directly with the PSD95 class of synaptic organizational proteins (Sheng and Kim, 1996). In contrast, because a majority of mammalian NR1 proteins include the $\mathrm{C} 2$ cassette, most mammalian NMDA receptor complexes interact with PSD95 proteins through the NR2 subunits. This difference may have significance for the organization of postsynaptic NMDA receptors within different organisms.

cDNA cloning and polymerase chain reaction (PCR) analysis have revealed the presence of two novel splice cassettes in the fish NR1 mRNA, which we have termed $\mathrm{C1}^{\prime}$ and C1" (Fig. 1B) (Bottai et al., 1998). These two segments, which can be present just before the $\mathrm{C} 1$ segment, are 19 and nine amino acid residues in length, respectively. The potential functional significance of $\mathrm{C}^{\prime}$ and $\mathrm{Cl}^{\prime \prime}$ is not known.

The fish $\mathrm{C} 1$ sequence differs from the mammalian sequence at seven of 37 residues (Fig. 2); however, these substitutions are highly conservative, maintaining charge and relative hydrophilicity at all positions except for a single serine $\rightarrow$ alanine substitution. Most importantly, the four protein kinase recognition sites and the high-affinity calmodulin-binding site identified in the mammalian $\mathrm{C} 1$ are maintained in the fish sequence. The functional significance of the $\mathrm{C} 1$ calmodulin-binding site is unknown; however; it has been shown that it is not required for $\mathrm{Ca}^{2+} /$ calmodulin inhibition, which is mediated by the low-affinity calmodulin site in $\mathrm{C} 0$ discussed above. To date, most of the evidence suggests that calmodulin and protein kinase interactions with C1 may be important for the control of the subcellular targeting of the NMDA receptor complex (Ehlers et al., 1996, 1998; Liu et al., 1994).

RNase protection studies indicate that in Apteronotus only $9 \%$ of brain NR1 mRNAs include the $\mathrm{C} 1$ segment and that the relative levels of NR1 C1+ mRNA vary among different brain regions, with highest levels in the hypothalamus (24\%), forebrain $(13 \%)$ and ELL $(12 \%)$. Interestingly, the C1+ splice form is not present in all neurons that express NR1, but rather displays a markedly heterogeneous pattern of expression. A good example is the ELL, where the C1+ form of NR1 mRNA is strongly expressed by pyramidal cells, but is not detectable in granule cells. Thus, NMDA receptors in pyramidal cell synapses are subject to regulation involving the $\mathrm{C} 1$ segment, while those in granule cells are not. This result suggests that, in ELL pyramidal cells, NMDA receptors undergo intracellular protein-protein interactions and/or protein phosphorylation involving the $\mathrm{C} 1$ segment and that these processes may play a special role in the targeting and/or control of ELL pyramidal cell NMDA currents.

\section{Discussion}

We have begun a molecular analysis of NMDA receptors by cloning the NR1 subunit from Apteronotus leptorhynchus cDNAs. The deduced amino acid sequence of aptNR1 is highly similar to that of other vertebrate NR1 subunits, suggesting that the fundamental properties of NMDA receptors are conserved across vertebrate species. The central role for NMDA-receptormediated neurotransmission in electrosensory processing is strongly supported by our finding that most electrosensory neurons express the NR1 subunit of the NMDA receptor. In the ELL, a particularly important role for NMDA receptors is suggested by the very high level of NMDA receptor gene expression in both pyramidal and granule cells. The amount of NR1 subunit mRNA in ELL pyramidal cells exceeds that detected in all other Apteronotus leptorhynchus CNS cell types.

Control of NMDA-receptor-mediated postsynaptic responses is determined by the selective expression of different receptor subunits in different neuronal types. For the NR1 subunit, different subtypes are generated through alternative RNA splicing of mRNAs transcribed from a single NR1 gene. We find that two of the three alternative splice cassettes (N1 and $\mathrm{C} 1$ ) previously described in mammals are present in the fish NR1 mRNAs. The third cassette (C2) was not detected in aptNR1 mRNA, although two novel sequences $\left(\mathrm{Cl}^{\prime}\right.$ and $\left.\mathrm{Cl}^{\prime \prime}\right)$ were detected. These results indicate that the control of NMDA receptor responses through alternative splicing of $\mathrm{N} 1$ and $\mathrm{C} 1$ predates the divergence of teleost and mammalian lineages, which suggests that the control of these two forms of NR1 is an important aspect of NMDA receptor function. A dramatic example of the control of the $\mathrm{C} 1$ alternative RNA splice cassette was found in neurons of the ELL, where $\mathrm{C} 1$ expression is restricted to pyramidal cells and excluded from granule cells. Thus, glutamate inputs to pyramidal cells, but not to granule cells, will be influenced through intracellular interactions such as protein kinase activities that are known to act on the $\mathrm{C} 1$ sequence. The very high level of NR1 expression in ELL pyramidal cells will assist in future studies determining the specific role of C1-mediated activities on NMDA receptor function and the contribution of this form of regulation to the control of electrosensory signal processing.

This work was supported by grants to R.J.D. and L.M. from the Medical Research Council of Canada. We thank William Ellis for technical support and Dr Peter Seeburg for the rat NR1 cDNA.

\section{References}

Anantharam, V., Panchal, R. G., Wilson, A., Kolchine, V. V., Treistman, S. N. and Bayley, H. (1992). Combinatorial RNA splicing alters the surface charge on the NMDA receptor. FEBS Lett. 305, 27-30.

Bastian, J. (1993). The role of amino acid neurotransmitters in the descending control of electroreception. J. Comp. Physiol. A 172, 409-423. 
Berman, N. J., Plant, J., Turner, R. W. and Maler, L. (1997). Excitatory amino acid receptors at a feedback pathway in the electrosensory system: implications for the searchlight hypothesis. J. Neurophysiol. 78, 1869-1881.

Bottai, D., Dunn, R. J., Ellis, W. and Maler, L. (1997). N-methylD-aspartate receptor $1 \mathrm{mRNA}$ distribution in the central nervous system of the weakly electric fish Apteronotus leptorhychus. J. Comp. Neurol. 389, 65-80.

Bottai, D., Maler, L. and Dunn, R. J. (1998). Alternative RNA splicing of the NMDA receptor NR1 mRNA in the neurons of the teleost electrosensory system. J. Neurosci. 18, 5191-5202.

Buller, A. L., Larson, H. C., Schneider, B. E., Beaton, J. A., Morrisett, R. A. and Monaghan, D. T. (1994). The molecular basis of NMDA receptor subtypes: native receptor diversity is predicted by subunit composition. J. Neurosci. 14, 5471-5484.

Dunah, A. W., Yasuda, R. P., Wang, Y. H., Luo, J. H., Davilagarcia, M. I., Gbadegesin, M., Vicini, S. and Wolfe, B. B. (1996). Regional and ontogenic expression of the NMDA receptor subunit $\mathrm{Nr} 2 \mathrm{~d}$ protein in rat brain using a subunit-specific antibody. J. Neurochem. 67, 2335-2345.

Durand, G. M., Bennett, M. V. and Zukin, R. S. (1993). Splice variants of the N-methyl-D-aspartate receptor NR1 identify domains involved in regulation by polyamines and protein kinase C. Proc. Natl. Acad. Sci. USA 90, 6731-6735.

Durand, J. (1993). Synaptic excitation triggers oscillations during NMDA receptor activation in rat abducens motoneurons. Eur. J. Neurosci. 5, 1389-1397.

Dye, J., Heiligenberg, W., Keller, C. H. and Kawasaki, M. (1989). Different classes of glutamate receptors mediate distinct behaviors in a single brainstem nucleus. Proc. Natl. Acad. Sci. USA 86, 8993-8997.

Ehlers, M. D., Fung, E. T., O'Brien, R. J. and Huganir, R. L. (1998). Splice variant-specific interaction of the NMDA receptor subunit NR1 with neuronal intermediate filaments. J. Neurosci. 18, 720-730.

Ehlers, M. D., Zhang, S., Bernhadt, J. P. and Huganir, R. L. (1996). Inactivation of NMDA receptors by direct interaction of calmodulin with the NR1 subunit. Cell 84, 745-755.

Farrant, M. and Cull-Candy, S. G. (1991). Excitatory amino acid receptor channels in Purkinje cells in thin cerebellar slices. Proc. R. Soc. Lond. B 244, 179-184.

Foldes, R. L., Rampersad, V. and Kamboj, R. K. (1993). Cloning and sequence analysis of cDNAs encoding human hippocampus Nmethyl-D-aspartate receptor subunits: evidence for alternative RNA splicing. Gene 131, 293-298.

Forsythe, I. D. and Westbrook, G. (1988). Slow excitatry postsynaptic currents mediated by N-methyl-D-aspartate receptors an cultured mouse central neurones. J. Physiol., Lond. 396, $515-533$.

Heiligenberg, W., Metzner, W., Wong, C. and Keller, C. (1996). Motor control of the jamming avoidance response of Apteronotus leptorhyncus - evolutionary changes of a behavior and its neuronal substrates. J. Comp. Physiol. 179, 653-674.

Hestrin, S., Sah, P. and Nicoll, R. A. (1990). Mechanisms generating the time course of dual component excitatory synaptic currents recorded in hippocampal slices. Neuron 5, 247-253.

Hollmann, M., Boulter, J., Maron, C., Beasley, J., Pecht, G. and Heinemann, S. (1993). Zinc potentiates agonist-induced currents at certain splice variants of the NMDA receptor. Neuron 10, 943-954.
Hollmann, M. and Heinemann, S. (1994). Cloned glutamate receptors. Annu. Rev. Neurosci. 17, 31-108.

Hollmann, M., Maron, C. and Heinemann, S. (1994). Nglycosylation site tagging suggests a three transmembrane domain topology for the glutamate receptor GluR1. Neuron 13, 1331-1343.

Ikeda, K., Nagasqwa, M., Mory, H., Araki, K., Sakimura, K., Watanabe, M., Inoue, Y. and Mishima, M. (1992). Cloning and expression of $\varepsilon 4$ subunits of the NMDA receptor channel. FEBS Lett. 313, 34-38.

Ishii, T., Moriyoshi, K., Sugihara, H., Sakurada, K., Kadotani, H., Yokoi, M., Akazawa, C., Shigemoto, R., Mizuno, N., Masu, M. and et al. (1993). Molecular characterization of the family of the N-methyl-D-aspartate receptor subunits. J. Biol. Chem. 268, 2836-2843.

Johnson, J. W. and Ascher, P. (1987). Glycine potentiates the NMDA response in cultured mouse brain neurons. Nature $\mathbf{3 2 5}$, 529-531.

Johnson, R. R., Jiang, X. and Burkhalter, A. (1996). Regional and laminar differences in synaptic localization of NMDA receptor subunit NR1 splice variants in rat visual cortex and hippocampus. J. Comp. Neurol. 368, 335-355.

Karp, S. J., Masu, M., Eki, T., Ozawa, K. and Nakanishi, S. (1993). Molecular cloning and chromosomal localization of the key subunit of the human N-methyl-D-aspartate receptor. J. Biol. Chem. 268, 3728-3733.

Kleckner, N. W. and Dingledine, R. (1988). Requirement for glycine in activation of NMDA-receptors expressed in Xenopus oocytes. Science 241, 835-837.

Krupa, M. and Crepel, F. (1990). Transient sensitivity of rat cerebellar Purkinje cells to N-methyl-D-aspartate during development. Eur. J. Neurosci. 2, 312-316.

Kurosawa, N., Kondo, K., Kimura, N., Ikeda, T. and Tsukada, Y. (1994). Molecular cloning and characterization of avian N-methylD-aspartate receptor type 1 (NMDA-R1) gene. Neurochem. Res. 19, 575-580.

Kutsuwada, T., Kashiwabuchi, N., Mori, H., Sakimura, K., Kushiya, E., Araki, K., Meguro, H., Masaki, H., Kumanishi, T., Arakawa, M. and et al. (1992). Molecular diversity of the NMDA receptor channel. Nature 358, 36-41.

Landwehrmeyer, G. B., Standaert, D. G., Testa, C. M., Penney, J. B. and Young, A. B. (1995). NMDA receptor subunit mRNA expression by projection neurons and interneurons in rat striatum. J. Neurosci. 15, 5297-5307.

Laube, B., Kuhse, J. and Betz, H. (1998). Evidence for a tetrameric structure of recombinant NMDA receptors. J. Neurosci. 18, 2954-2961.

Laurie, D. J., Putzke, J., Zieglgansberger, W., Seeburg, P. H. and Tolle, T. R. (1995). The distribution of splice variants of the NMDAR1 subunit mRNA in adult rat brain. Mol. Brian Res. 32, 94-108.

Laurie, D. J. and Seeburg, P. H. (1994). Regional and developmental heterogeneity in splicing of the rat brain NMDAR1 mRNA. J. Neurosci. 14, 3180-3194.

Lester, R. A. J., Clements, J. D., Westbrook, G. L. and Jahr, G. (1990). Channel kinetics determine the time course of NMDA receptor mediated synaptic currents. Nature 346, 565-567.

Liu, H., Wang, H., Sheng, M., Jan, L. Y., Jan, Y. N. and Basbaum, A. I. (1994). Evidence for presynaptic N-methyl-D-aspartate autoreceptors in the spinal cord dorsal horn. Proc. Natl. Acad. Sci. USA 91, 8383-8387.

MacDonald, J. F., Porietis, A. V. and Wojtowicz, J. M. (1982). L- 
Aspartic acid induces a region of negative slope conductance in the current voltage relationship of cultured spinal cord neurones. Brain Res. 237, 248-253.

Maler, L. and Monaghan, D. (1991). The distribution of excitatory amino acid binding sites in the brain of an electric fish, Apteronotus leptorhynchus. J. Chem. Neuroanat. 4, 39-61.

Mayer, M. L., Westbrook, G. L. and Gutherie, P. B. (1984). Voltage-dependent block by $\mathrm{Mg}^{2+}$ of NMDA responses in spinal cord neurons. Nature 309, 261-263.

Meguro, H., Mori, H., Araki, K., Kushiya, E., Kutsuwada, T., Yamazaki, M., Kumanishi, T., Arakawa, M., Sakimura, K. and Mishina, M. (1992). Functional characterization of a heteromeric NMDA receptor channel expressed from cloned cDNAs. Nature 357, 70-74.

Monyer, H., Burnashev, N., Laurie, D. J., Sakmann, B. and Seeburg, P. H. (1994). Developmental and regional expression in the rat brain and functional properties of four NMDA receptors. Neuron 12, 529-540.

Monyer, H., Sprengel, R., Schoepfer, R., Herb, A., Higuchi, M., Lorneli, H., Burnashev, N., Sakmann, B. and Seeburg, P. H. (1992). Heteromeric NMDA receptors: molecular and functional distinction of subtypes. Science 256, 1217-1221.

Moriyoshi, K., Masu, M., Ishii, T., Shigemoto, R., Mizuno, N. and Nakanishi, S. (1991). Molecular cloning and characterization of the rat NMDA receptor. Nature 354, 31-37.

Nakanishi, N., Axel, R. and Shneider, N. A. (1992). Alternative splicing generates functionally distinct $\mathrm{N}$-methyl-D-aspartate receptors. Proc. Natl. Acad. Sci. USA 89, 8552-8556.

Nicoll, R. A., Malenka, R. C. and Kauer, J. A. (1990). Functional comparison of neurotransmitter receptor subtypes in mammalian central nervous system. Physiol. Rev. 70, 513-565.

Nowak, L., Bregestovski, P., Ascher, P., Herbet, A. and Prochiantz, A. (1984). Magnesium gates glutamate-activated channels in mouse central neurons. Nature 307, 462-465.

O'Hara, P. J., Sheppard, P. O., Thogersen, H., Venezia, D., Haldeman, B. A., McGrane, V., Houamed, K. M., Thomsen, C., Gilbert, T. L. and Mulvihill, E. R. (1993). The ligand-binding domain in metabotropic glutamate receptors is related to bacterial periplasmic binding proteins. Neuron 11, 41-52.

Paupard, M. C., Friedman, L. K. and Zukin, R. S. (1997). Developmental regulation and cell-specific expression of $\mathrm{N}$ methyl-D-aspartate receptor splice variants in rat hippocampus. Neurosci. 79, 399-409.

Perkel, D. J., Hestrin, S., Sah, P. and Nicholl, R. A. (1990). Excitatory synaptic currents in Purkinje cells. Proc. R. Soc. Lond. $B$ 241, 116-121.

Petralia, R. S., Wang, Y. X. and Wenthold, R. J. (1994a). The NMDA receptor subunits NR2A and NR2B show histological and ultrastructural localization patterns similar to those of NR1. $J$. Neurosci. 14, 6102-6120.

Petralia, R. S., Yokotani, N. and Wenthold, R. J. (1994b). Light and electron microscope distribution of the NMDA receptor subunit NMDAR1 in the rat nervous system using a selective anti-peptide antibody. J. Neurosci. 14, 667-696.

Planells-Cases, R., Sun, W., Ferrer-Montiel, A. V. and Montal, M. (1993). Molecular cloning, functional expression and pharmacological characterization of an N-methyl-D-aspartate receptor subunit from human brain. Proc. Natl. Acad. Sci. USA 90, 5057-5061.
Sheng, M. and Kim, E. (1996). Ion channel associated proteins. Curr. Opin. Neurobiol. 6, 602-608.

Shumway, C. A. (1989a). Multiple electrosensory maps in the medulla of weakly electric gymnotiform fish. I. Physiological differences. J. Neurosci. 9, 4388-4399.

Shumway, C. A. (1989b). Multiple electrosensory maps in the medulla of weakly electric gymnotiform fish. II. Anatomical differences. J. Neurosci. 9, 4400-4415.

Soloviev, M. M., Brierley, M. J., Shao, Z. Y., Mellor, I. R., Volkova, T. M., Kamboj, R., Ishimaru, H., Sudan, H., Harris, J., Foldes, R. L., Grishin, E. V., Usherwood, P. N. R. and Barnard, E. A. (1996). Functional expression of a recombinant unitary glutamate receptor from Xenopus, which contains Nmethyl-D-aspartate (NMDA) and non-NMDA receptor subunits. $J$. Biol. Chem. 271, 32572-32579.

Standaert, D. G., Landwehrmeyer, G. B., Kerner, J. A., Penney, J. B. and Young, A. B. (1996). Expression Of NMDAr2d glutamate receptor subunit mRNA in neurochemically identified interneurons in the rat neostriatum, neocortex and hippocampus. Mol. Brain Res. 42, 89-102.

Standaert, D. G., Testa, C. M., Young, A. B. and Penney, J. B., Jr (1994). Organization of N-methyl-D-aspartate glutamate receptor gene expression in the basal ganglia of the rat. J. Comp. Neurol. 343, 1-16.

Stern-Bach, Y., Bettler, B., Hartley, M., Sheppard, P. O., O'Hara, P. J. and Heinemann, S. F. (1994). Agonist selectivity of glutamate receptors is specified by two domains structurally related to bacterial amino acid-binding proteins. Neuron 13, 1345-1357.

Sugihara, H., Moriyoshi, K., Ishii, T., Masu, M. and Nakanishi, S. (1992). Structures and properties of 7 isoforms of the NMDA receptor generated by alternative splicing. Biochem. Biophys. Res. Commun. 185, 826-832.

Traynelis, S. F., Burgess, M. F., Zheng, F., Lyuboslavsky, P. and Powers, J. L. (1998). Control of voltage-independent zinc inhibition of NMDA receptors by the NR1 subunit. J. Neurosci. 18, 6163-6175.

Traynelis, S. F., Hartley, M. and Heinemann, S. F. (1995). Control of proton sensitivity of the NMDA receptor by RNA splicing and polyamines. Science 268, 873-876.

Vicini, S., Wang, J. F., Li, J. H., Zhu, W. J., Wang, Y. H., Luo, J. H., Wolfe, B. B. and Grayson, D. R. (1998). Functional and pharmacological differences between recombinant N-methyl-Daspartate receptors. J. Neurophysiol. 79, 555-566.

Watanabe, M., Mishina, M. and Inoue, Y. (1994). Distinct spatiotemporal distributions of the N-methyl-D-aspartate receptor channel subunit mRNAs in the mouse cervical cord. J. Comp. Neurol. 345, 314-319.

Wo, G. Z. and Oswald, R. E. (1994). Transmembrane topology of two kainate receptor subunits revealed by $\mathrm{N}$-glycosylation. Proc. Natl. Acad. Sci. USA 91, 7154-7158.

Zhang, S., Ehlers, M. D., Bernhardt, J. P., Su, C.-T. and Huganir, R. L. (1998). Calmodulin mediates calcium-dependent inactivation of N-methyl-D-aspartate receptors. Neuron 21, 443-453.

Zheng, F., Gingrich, M. B., Traynelis, S. F. and Conn, P. J. (1998). Tyrosine kinase potentiates NMDA receptor currents by reducing tonic zinc inhibition. Nature Neurosci. 1, 185-191.

Zheng, X., Zhang, L., Durand, G. M., Bennett, M. V. and Zukin, R. S. (1994). Mutagenesis rescues spermine and $\mathrm{Zn}^{2+}$ potentiation of recombinant NMDA receptors. Neuron 12, 811-818. 